\title{
Activated Carbon Addition Methods on the Pre-impregnation Process of Co-Mo in Y-Zeolite Ultra Stable: A Properties Exploration and Enhancement of Metals Loaded
}

\author{
Yuniawan Hidayat ${ }^{1 *}$, Khoirina Dwi Nugrahaningtyas ${ }^{1}$, Priska Julia Hendrastuti ${ }^{1}$ \\ ${ }^{1}$ Department of Chemistry, Universitas Sebelas Maret, Central Java, Indonesia
}

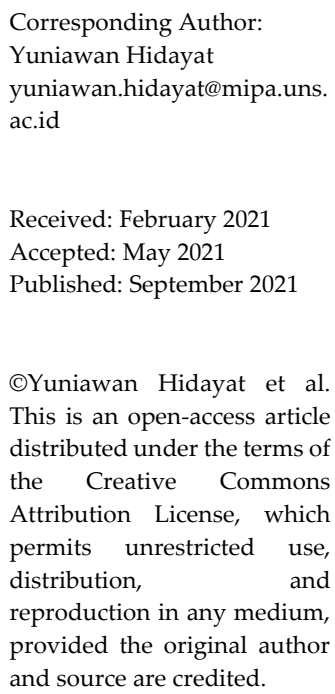

Received: February 2021 Accepted: May 2021 Published: September 2021

CYuniawan Hidayat et al. This is an open-access article distributed under the terms of the Creative Commons Attribution License, which permits unrestricted use distribution, and reproduction in any medium, provided the original author and source are credited.

\begin{abstract}
The amount of loaded Co-Mo metal on the Y-Zeolite Ultra Stable (USY) was increased by the addition of activated carbon in the pre-impregnation process. USY modification was done by adding activated carbon to USY as much as $10 \mathrm{wt} \%$. The process of adding activated carbon is carried out by three methods, i.e., grinding with sucrose binder (ACU1), without sucrose (ACU2), and conducting by ball milling (ACU3). Wet impregnation method was employed to disperse the Co and Mo, sequentially. Composites were characterized using Fourier Transform Infrared (FTIR), X-ray diffraction (XRD), and surface area analyzer (SAA). Metal dispersions were observed by $X$-ray fluorescence (XRF). The FTIR suggests an interaction between USY and activated car-bon, while the XRD result indicated the none structural transformation of USY zeolite. The SAA analysis showed an increased total pore radius with the activated carbon addition. The XRF confirmed the increasing of total metals dispersion of $6.25 \%$ (ACU1); $5.48 \%(\mathrm{ACU} 2) ; 5.18 \%$ (ACU3); compare to USY origin with $3.28 \%$ metals loaded.
\end{abstract}

Keywords: activated carbon, USY, pre-impregnation, Co, Mo

\section{Introduction}

The embedded transition metal in the host material can increase the selectivity and catalyst activity $^{[1]}$. The combination of two metals as a bimetallic catalyst shows an improved optical, electronic, and catalytic properties than a single metal ${ }^{[2]}$.

It is challenging to disperse metals into the host material in a large amount. There are no definite of the best methods to embed metals on it. In fact, various factors responsible for it, including surface area, pore size, metal size, and the host material's cation-exchange capacity. The method of such as co-impregnation with sequential metal loading was reported successfully to increase metals dispersion in zeolites ${ }^{[3]-[6]}$.
The deposition process of transition metals in the zeolite is generally carried out by the wet impregnation or cation exchange methods. Technically, it simple, less time consumed, and less waste remained. However, it resulted a nonuniform dispersion, depending on the methods; metals; and zeolite type. Homogeneity and metals aggregate formed over the host affect the effectiveness and selectivity of catalyst[7]-[12].

Combining alumina and zeolite with activated carbon as a composite improves the efficiency of their adsorption to heavy metal contaminants. Active carbon is used to trap the adsorbed metals by utilizing its pores and active group ${ }^{[13]-}$ [16]. The addition of activated carbon in porous materials is expected to increase the number of transition metals loaded in the wet 
impregnation phase. The technique on adding the activated carbon to the zeolite needs to be studied because potentially counterproductive, such as blocking pores, reducing acidity, or damaging the zeolite structure in high pressure.

In previous research, the conducted coimpregnation of Co and Mo metals into USY zeolites with various concentrations of $\mathrm{Co}$ and Mo precursors. The maximum of the total loaded metals is less than $5 \mathrm{wt}^{0} \mathrm{[}^{[17],[18]}$. This paper discus the effect of the adding methods of activated carbon by $10 \mathrm{wt} \%$ in USY to the catalyst properties and the amount of Co and Mo metals loaded. Compositing an activated carbon with other solid materials can be done by grinding using porcelain or ball milling [199,[20]. The two method were conducted on porcelain by grinding with sucrose binder (ACU1), grinding without sucrose (ACU2). The third method was conducted in the ball milling (ACU3).

\section{Experimental}

\section{Materials}

Coconut shell, distilled water, aquabidest, $\mathrm{H}_{2} \mathrm{SO}_{4}$ (pro analysis $98 \%$, E. Merck), sucrose (pro analysis, E. Merck), USY (Tosoh Corporation, Japan), ammonium heptamolybdate tetrahydrate $\left[\left(\mathrm{NH}_{4}\right)_{6} \mathrm{Mo}_{7} \mathrm{O}_{24} \cdot 4 \mathrm{H}_{2} \mathrm{O}\right]$ (p.a, Merck), cobalt(II) nitrate hexahydrate $\left[\mathrm{Co}\left(\mathrm{NO}_{3}\right)_{2} \cdot 6 \mathrm{H}_{2} \mathrm{O}\right]$ (p.a, Merck), ammonia [NH 3 (p.a 12\%, Merck), $\mathrm{N}_{2}, \mathrm{O}_{2}, \mathrm{H}_{2}$ from PT Samatour.

\section{Instruments}

X-ray diffraction (XRD, Philips X'Pert diffractometer), surface area analyzer (SAA, Nova e- series), Fourier transform infrared (FTIR-8201 PC) (range of wave numbers between $400-4000 \mathrm{~cm}^{-1}$ ), X-ray fluorescence (XRF, Bruker S2 Ranger).

\section{Methods}

Activated carbon is produced from coconut shells following the Yusmartini et al process ${ }^{[21]}$ Activated carbon tested refers to the Indonesian National Standard (SNI) 06-3730-1995, including the determination of yield, moisture content, flight substance content, and ash content. Activation methods of the USY zeolite was following Nugrahaningtyas et al[17]. The process of adding activated carbon-zeolite USY (ACU) was carried out as follows, $17 \mathrm{~g}$ of USY and 10 $w t \% \mathrm{KA}$ were added and crushed firmly in a porcelain mortar and then added $1 \mathrm{~mL}$ of saturated solution of sucrose as a binder for $1 \mathrm{~h}$. The resulting paste is then stored for $24 \mathrm{~h}$ and dried in an oven at $105{ }^{\circ} \mathrm{C}$ for $1 \mathrm{~h}$. Dried samples were calcined at a temperature of $250{ }^{\circ} \mathrm{C}$ and labelled as ACU1. The method was repeated with the same steps without the addition of sucrose and labelled as ACU2. The last method, the addition of activated carbon was done by ball milling for $1 \mathrm{~h}$ at a speed of $350 \mathrm{rpm}$ and labeled as ACU3. The three of ACU were analyzed using FTIR to identify existing functional groups. The XRD was performed to determine the impact of adding $\mathrm{KA}$ on the crystallinity of USY. The BET method to determine surface area and the pore radius was performed using SAA.

An ammonia solution with the same concentration of $3.186 \mathrm{M}$ for $18 \mathrm{~mL}$ was applied to every $15 \mathrm{~g}$ of ACU1, ACU2, and ACU3. An $\left[\left(\mathrm{NH}_{4}\right)_{6} \mathrm{Mo}_{7} \mathrm{O}_{24} \cdot 4 \mathrm{H}_{2} \mathrm{O}\right]$ with a metal precursor concentration of $0.037 \mathrm{M}$ was added to the solution, followed by a reflux procedure at $60^{\circ} \mathrm{C}$ for $2 \mathrm{~h}$. After $2 \mathrm{~h}$, the residual filtered sample was put in a volumetric flask and added with $\left[\mathrm{Co}\left(\mathrm{NO}_{3}\right)_{2} \cdot 6 \mathrm{H}_{2} \mathrm{O}\right]$ salt with a concentration of $0.018 \mathrm{M}$ of the metal precursor Mo, then heated under reflux at $60^{\circ} \mathrm{C}$ for $2 \mathrm{~h}$. The sample is then filtered, and the residue is dried using a vacuum evaporator at a pressure of $72 \mathrm{mbar}$ and a temperature of $40{ }^{\circ} \mathrm{C}$ until the sample is dry and becomes a powder. For comparison, in the same procedure, the metals impregnation was carried out in USY without the addition of activated carbon.

The dried powder sample was then calcined with $\mathrm{N}_{2}$ at $550{ }^{\circ} \mathrm{C}$ for $3 \mathrm{~h}$, followed by an oxidizing procedure using $\mathrm{O}_{2}$ at $400{ }^{\circ} \mathrm{C}$ for $2 \mathrm{~h}$, then reduced by $\mathrm{H}_{2}$ gas at $400{ }^{\circ} \mathrm{C}$ for $2 \mathrm{~h}$. The amount of metal carried was analyzed using XRF. 


\section{Results and Disscusion}

Figure 1 shows the FTIR results of the five samples, namely, activated carbon, USY, ACU1, ACU2, and ACU3. Depicted in Figure 1A, the O$\mathrm{H}$ spectra of activated carbon have a broad peak at wave number $3441.16 \mathrm{~cm}^{-1}$. An absorption band at wave number $1189.17 \mathrm{~cm}^{-1}$ is also observed, which belongs to C-O vibration from carboxylic acids, alcohols, phenols, or esters. At the wave number $1695.50 \mathrm{~cm}^{-1}$, a $\mathrm{C}=\mathrm{O}$ vibration generally comes from the carboxylic acids, ketones, aldehydes, or esters. The aromatic $C=C$ functional group appears at wave number $1589.41 \mathrm{~cm}^{-1[22]}$.

For the USY, the wave number of $\mathrm{O}-\mathrm{H}$ vibration appears at $3388.11 \mathrm{~cm}^{-1}$, originating from the Si$\mathrm{OH}$ and $\mathrm{Al}-\mathrm{OH}$ groups special for $\mathrm{O}-\mathrm{H}$ stretch. Meanwhile, the characteristic appears around $1500-1600 \mathrm{~cm}^{-1}$ denoted as $\mathrm{O}-\mathrm{H}$ bend from those groups ${ }^{[23]}$. The Si-O and Al-O vibration were shown by the absorption at $821.71 \mathrm{~cm}^{-1}$ and $1020.39 \mathrm{~cm}^{-1}$, respectively. The peak of the spectra at wave number $456.18 \mathrm{~cm}^{-1}$ shows the bending mode of Si-O and Al-O.

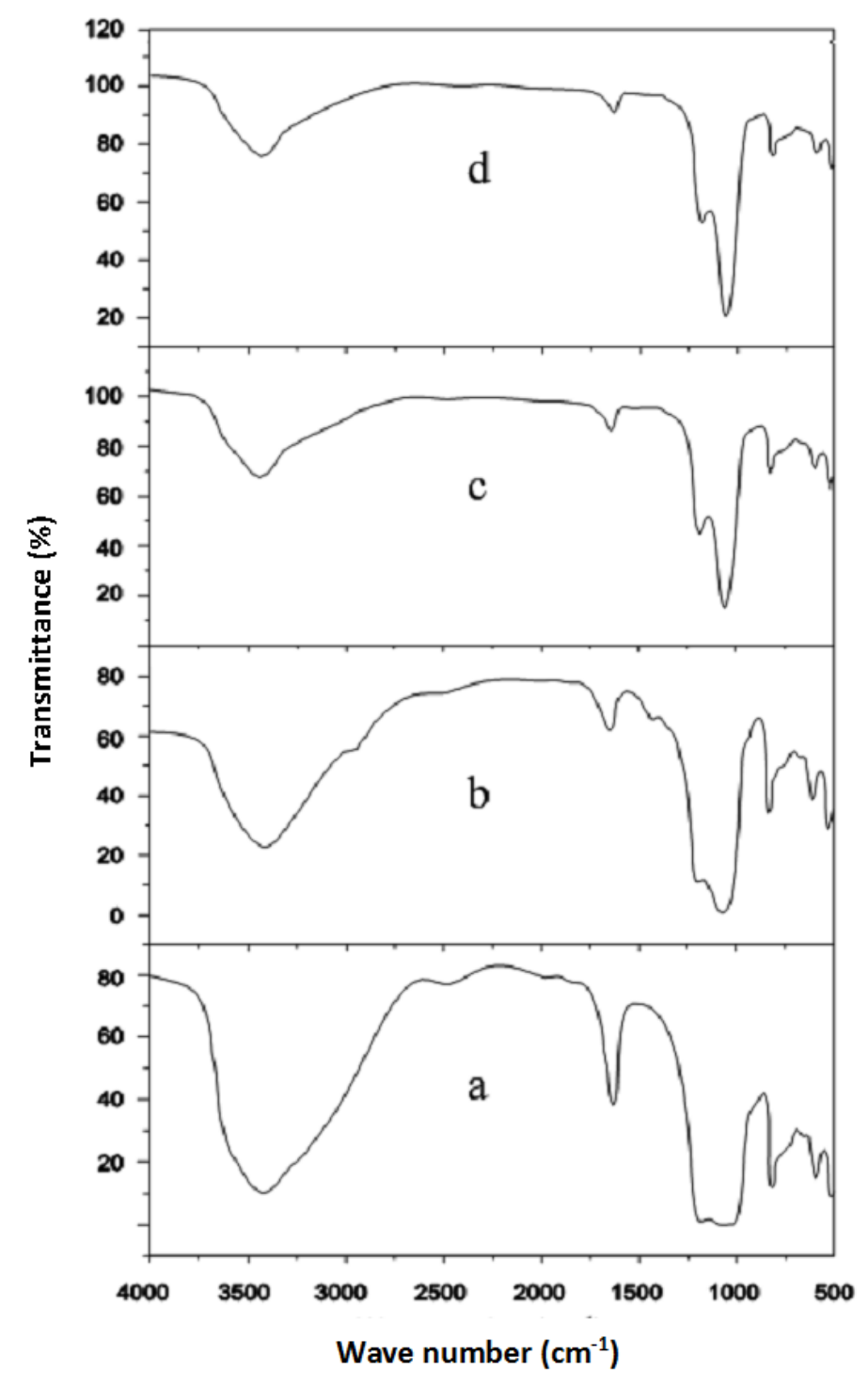

Figure 1. The FTIR spectra of (a) USY, (b) ACU1, (c) ACU2, (d) ACU3. 
The wave number of $3500 \mathrm{~cm}^{-1}$ is also observed for ACU1, ACU2, and ACU3, which indicates OH groups' presence. However, it is smaller than the USY's spectra, confirming less silanol or aluminol sites on USY with the activated carbon's presence. The intensity of the spectra at the wave numbers around $1500 \mathrm{~cm}^{-1}$ and 1600 $\mathrm{cm}^{-1}$ is also reduced. It confirms that the $\mathrm{O}-\mathrm{H}$ bend of USY restrain by the activated carbon. The spectra's difference at the corresponding wave number indicates the possibility of interaction of silanol and aluminol groups with $\mathrm{O}-\mathrm{H}, \mathrm{C}=\mathrm{O}$ or $\mathrm{C}=\mathrm{C}$ of activated carbon. In fact, the only possibility of hydrogen bonding between USY and activated carbon is via silanol or aluminol groups with the carbon's group which rich of electron. Around 1300-1000 $\mathrm{cm}^{-1}$ show the deformation of the spectra. The spectra at the corresponds number shows the characteristics of activated carbon groups, agree with the FTIR result of activated carbon reported in the previous paper[24],[25]. By that, the USY and the activated carbon was a physical interaction.
The crystallinity of the ACUs was analyzed using XRD qualitatively. The analysis is conducted at a range of $2 \theta=5-90^{\circ}$. The diffractograms of the USY was fitted using standard data of the Crystallography Open Database. Figure 2 shows the diffractogram of the USY matching with the COD No. 96-3000175 (A14.8 Na0.7 O24 Si7.2); COD No. 96-1536102 (A12.96 O22.32 Si8.94), and COD No. 96152-9944 (A157.0048 Li46 O384 Si134.995). The correspond standard FoM (Figure of Merit) and present phase quantity are $0.95(87.7 \%), 0.95$ $(6.2 \%)$ and $0.93(6.1 \%)$, respectively. The $2 \theta$ characteristics of USY of $6.2 ; 10.2 ; 11.9 ; 15.7 ; 23.8$; $27.9 ; 31.6$; and $34.3^{\circ}$ fit the standard. This $2 \theta$ pattern is compatible with the USY refinement approach that correlates to the ICSD \#31542 data

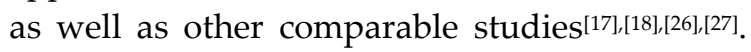
The activated carbon in amorphous phase has $2 \theta$ characteristic of $24^{\circ}[24],[25],[28]-[30]$, it overlaps to the USY characteristic.

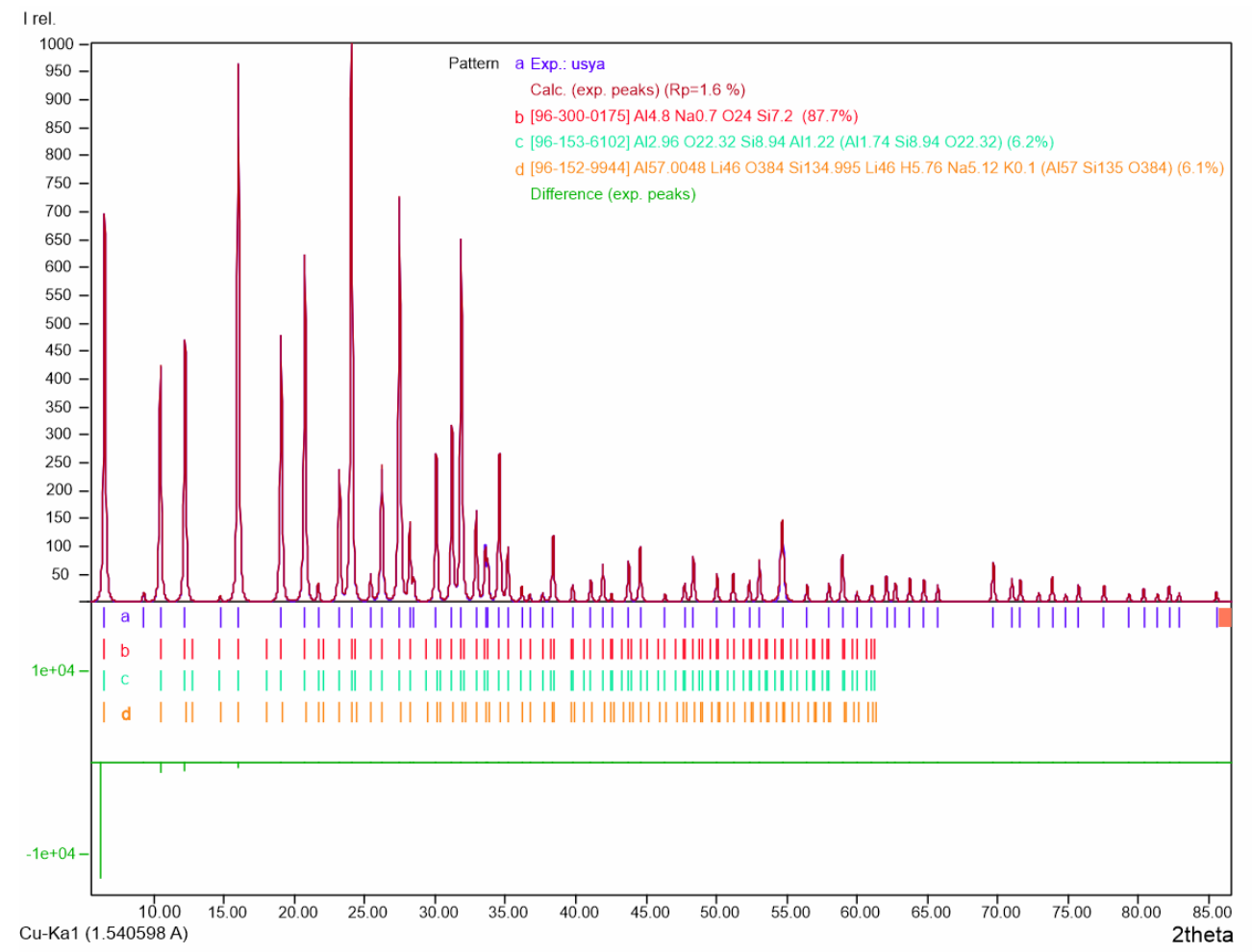

Figure 2. The USY diffractogram pattern match to the standard COD No. 96-300-0175 (A14.8 Na0.7 O24 Si7.2); COD No. 96-153-6102 (Al2.96 O22.32 Si8.94), and COD No. 96-152-9944 (A157.0048 Li46 O384 Si134.995). 
The addition of the carbon standard to the XRD pattern using a refinery method do not give satisfying result, covered by the strong similarity of the USY pattern as shown in Figure 3.

Figure 3 shows the characteristics of ACUs with a similar pattern to the USY at corresponds $2 \theta$, affirming no d-spacing shifting after the addition of activated carbon. In order to predict the similarity of the crystal phase, the total peak area of each ACU is then compared to the USY. The dashed line shows the cumulative area of peaks. Figures $3 b, 3 c$, and $3 d$ depict the cumulative peaks of ACU1, ACU2, and ACU3 less than the USY (Figure 3a) with the similarity of $84.3 \%, 98.6 \%$, and $58.2 \%$, respectively. The procedures to incorporate the activated carbon affected the USY's crystallinity. In ACU3, an effective crushing method with ball milling significantly reduced the crystallinity.

The surface area properties of the activated carbon, USY, and the three ACUs were determined using $\mathrm{N}_{2}$ isothermal adsorptiondesorption. An open-loop hysteresis has occurred in the activated carbon's curve. It resulted from the adsorption-desorption, which does not overlap at the lower $\mathrm{p} / \mathrm{p}_{\mathrm{o}}$ (Figure 4).

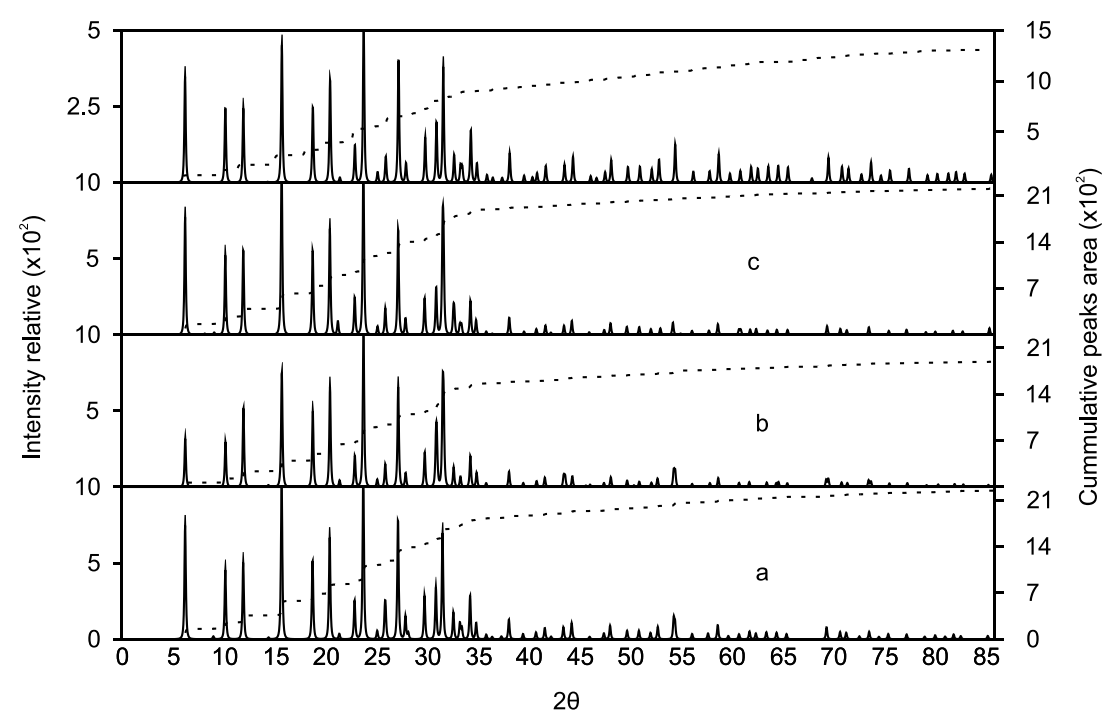

Figure 3. The diffractogram (a) USY, (b) ACU1, (c) ACU2, (d) ACU3.

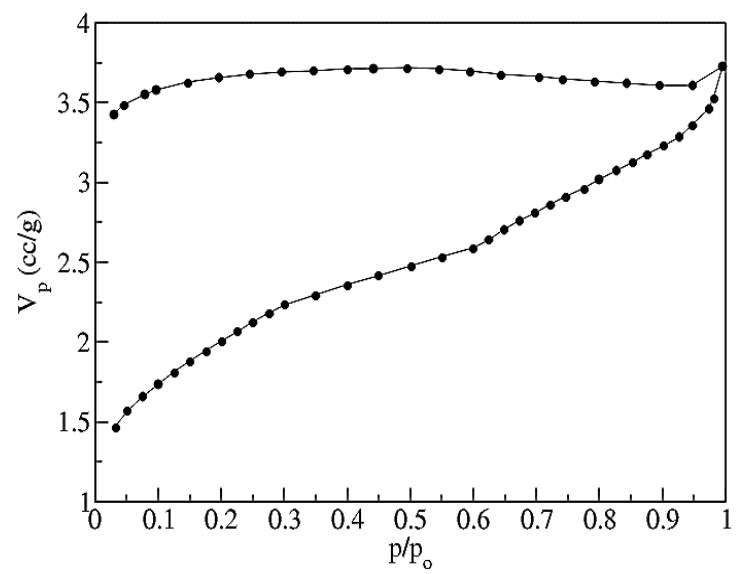

Figure 4. Adsorption desorption isotherm of activated carbon. 
Table 1. Analysis result of surface area, pore volume and pore radius

\begin{tabular}{cccc}
\hline Type & Surface Area $\left(\mathbf{m}^{2} / \mathbf{g}\right)$ & $\begin{array}{c}\text { Total Pore Volume } \\
(\mathbf{c c} / \mathbf{g})\end{array}$ & $\begin{array}{c}\text { Pore Radius } \\
(\AA)\end{array}$ \\
\hline AC & 48.4 & 0.02 & 29.00 \\
USY & 627.8 & 0.10 & 15.30 \\
ACU1 & 184.2 & 0.19 & 21.27 \\
ACU2 & 435.4 & 0.33 & 15.20 \\
ACU3 & 423.2 & 0.33 & 16.20 \\
\hline
\end{tabular}

When depressurization is processed, the adsorbed $\mathrm{N}_{2}$ remains in the micropore. However, according to the multipoint BET analysis, activated carbon has a large pore radius of $29 \AA$ with a surface area of $48.4 \mathrm{~m}^{2} / \mathrm{g}$ (Table 1).

The curves for adsorption-desorption of all ACUs are below the USY. As seen in Figure 5a, the amount of adsorbed N2 in the USY is superior to the three ACUs, confirming a less surface area than USY. An open-loop hysteresis is seen in Figure $5 b$, affirming a carbon surface character in the ACU1. The ACU1 has the lowest surface area; the adsorbed $\mathrm{N}_{2}$ volume is smaller than that of other ACUs. A greater pore size, however, is confirmed by the broader region of loop hysteresis. Closed-loop hysteresis was observed for ACU2 and ACU3 at a p/po of 0.4 to 1 (Figures 5c and 5d). The ACU2 and ACU3 curves are above the ACU1, indicating that there is a larger surface area. In detail, Table 1 displays the surface properties of the related materials.
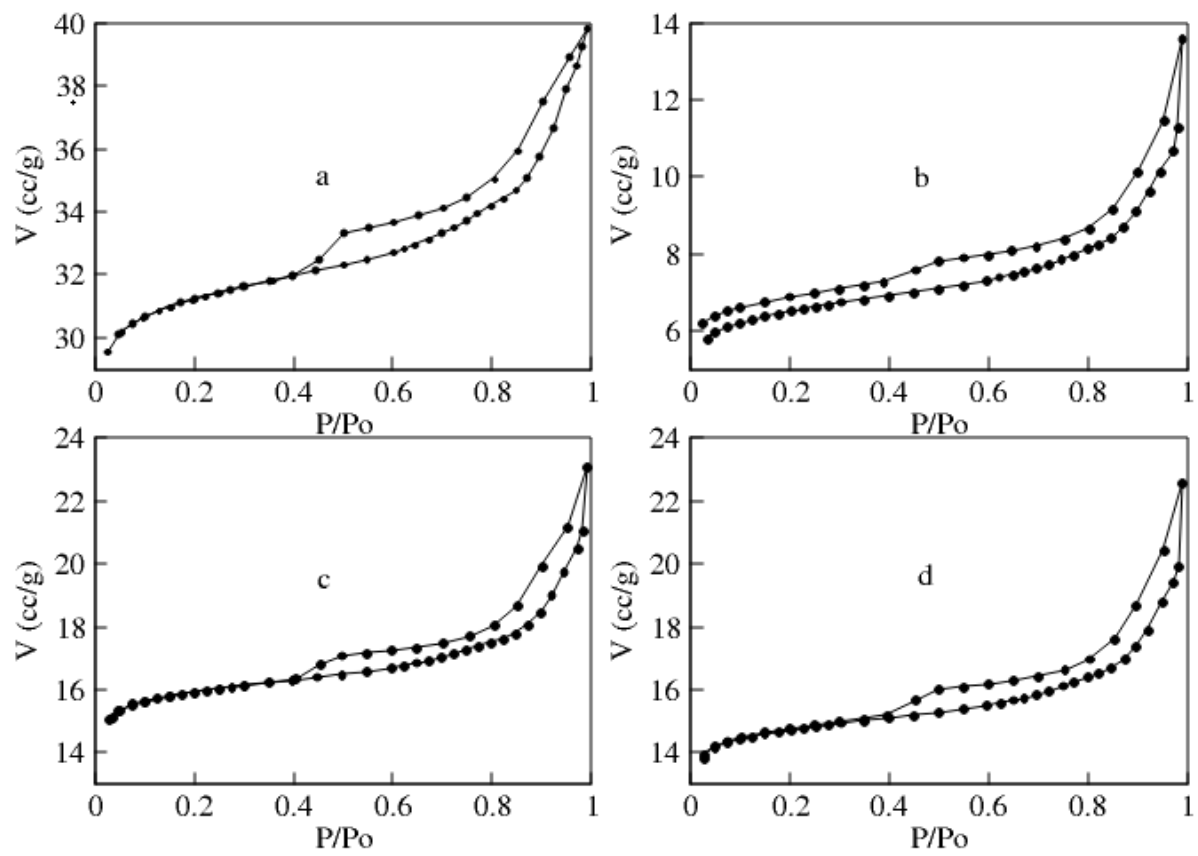

Figure 5. Adsorption-desorption isotherm (a) USY, (b) ACU1, (c) ACU2, (d) ACU3. 
Table 2. The XRF result of metals content

\begin{tabular}{cccc}
\hline Name & Co (\%) & Mo (\%) & Total (\%) \\
\hline USY & 2.63 & 0.65 & 3.28 \\
ACU1 & 5.15 & 1.10 & 6.25 \\
ACU2 & 3.78 & 1.70 & 5.48 \\
ACU3 & 3.67 & 1.51 & 5.18 \\
\hline
\end{tabular}

Table 1 illustrates in detail the effect of activated carbon on the surface properties of the three ACUs. The presence of activated carbon typically lowers the surface area and increases the pore radius of ACUs. The BET calculation indicates that the ACU2 and ACU3 surface area of $435.4 \mathrm{~m}^{2} / \mathrm{g}$ and $423.2 \mathrm{~m}^{2} / \mathrm{g}$ are greater than the ACU1 $\left(184.2 \mathrm{~m}^{2} / \mathrm{g}\right)$. The total pore volume of ACU2 and ACU3 are higher than ACU1, but the pore radius is reciprocal. With a smaller pore radius and a large surface area, the ACU2 and ACU3 more porous than ACU1. Conversely, the ACU1 has a larger pore but is less porous. Carbon compaction can be caused by the addition of the sucrose process in ACU1 preparation; as it is crushed, the carbon formed over USY is more aggregate than a powder. Consequently, the large pore size is estimated. The effect of sucrose binders on the oxide surface causing carbon compactions is shown by Shi et al and Irwin and Pirro[31,,[32].

The XRF analysis was used to determine Co $(\mathrm{CoO})$ and $\mathrm{Mo}\left(\mathrm{MoO}_{3}\right)$ after the impregnation process in those ACUs. Table 2 shows that activated carbon increases the amount of impregnated Co and Mo. In more depth, the metal content of Co was $5.15 \%$ higher in ACU1 compared to ACU2 and ACU3. The ACU2, by comparison, has the highest Mo content of $1.70 \%$. The most dominant variable is the pore radius size of ACU1 that accommodates more Co metal. The Mo metal was loaded after the Co metal; thus, Mo would be spread on the surface of ACU when ACU's pore is filled with Co. Thus, more Mo metal can accommodate ACUs with the highest surface area. Driven by the higher Co metal contribution, ACU1 has the highest total metal content (Co and Mo). Compared with the grinding process on porcelain, the use of ball milling during the preparation of ACU3 did not have a significant effect in terms of metal accommodation.

\section{Conclusions}

The amount of loaded Co and Mo metals has usually been effectively increased by adding activated carbon in the USY due to an improvement in the pore size of all ACUs. No structural replacement of the USY is observed, confirmed by the matched of 2teta XRD. Carbon compaction over the USY surface is caused by sucrose as a binder, drastically enhancing the ACU1 pore radius. Consequently, the total amount of metal Co and Mo loaded in the ACU1 is the highest, followed by ACU2 and ACU3. The grinding method or ball milling at the preparation stage does not correspond to a significant improvement in the material characteristics, and the number of loaded metals remains the same.

\section{References}

1. Ludwig, J. R. \& Schindler, C. S., Catalyst: sustainable catalysis. Chem, 2(3): 313-316 (2017).

2. Dutta, S., Ray, C., Sarkar, S., Roy, A., Sahoo, R. \& Pal, T., Facile synthesis of bimetallic $\mathrm{Au}-\mathrm{Pt}, \mathrm{Pd}-\mathrm{Pt}$, and Au-Pd nanostructures: enhanced catalytic performance of $\mathrm{Pd}-\mathrm{Pt}$ analogue towards fuel cell application and electrochemical sensing. Electrochim. Acta, 180: 1075-1084 (2015). 
3. Ostgard, D. J., Kustov, L., Poeppelmeier, K. R. \& Sachtler, W. M. H., Comparison of $\mathrm{Pt} / \mathrm{KL}$ catalysts prepared by ion exchange or incipient wetness impregnation. J. Catal., 133(2): 342-357 (1992).

4. Qiu, S., Zhang, X., Liu, Q., Wang, T., Zhang, Q. \& Ma, L., A simple method to prepare highly active and dispersed Ni/MCM-41 catalysts by co-impregnation. Catal. Commun., 42: 73-78 (2013).

5. Flores, C., Batalha, N., Marcilio, N. R., Ordomsky, V. V. \& Khodakov, A. Y., Influence of impregnation and ion exchange sequence on metal localization, acidity and catalytic performance of cobalt BEA zeolite catalysts in Fischer-Tropsch synthesis. ChemCatChem, 11(1): 568-574 (2019).

6. Kinger, G., Lugstein, A., Swagera, R., Ebel, M., Jentys, A. \& Vinek, H., Comparison of impregnation, liquid-and solid-state ion exchange procedures for the incorporation of nickel in HMFI, HMOR and HBEA: Activity and selectivity in n-nonane hydroconversion. Microporous Mesoporous Mater., 39(1-2): 307-317 (2000).

7. Mohamed, E. F., Awad, G., Zaitan, H., Andriantsiferana, C. \& Manero, M.-H., Transition metals-incorporated zeolites as environmental catalysts for indoor air ozone decomposition. Environ. Technol., 39(7): 878-886 (2018).

8. Kristiani, A., Sudiyarmanto, S., Aulia, F., Hidayati, L. N. \& Abimanyu, H., Metal supported on natural zeolite as catalysts for conversion of ethanol to gasoline. in MATEC Web of Conferences, 101: 01001 EDP Sciences, (2017).

9. Sumari, S., Fajaroh, F., Suryadharma, I. B., Santoso, A. \& Budianto, A., Zeolite impregnated with $\mathrm{Ag}$ as catalysts for glycerol conversion to ethanol assisted by ultrasonic. in IOP Conference Series: Materials Science and Engineering, 515(1): 012075 IOP Publishing, (2019).

10. Miskolczi, N., Juzsakova, T. \& Sója, J., Preparation and application of metal loaded ZSM-5 and y-zeolite catalysts for thermo-catalytic pyrolysis of real end of life vehicle plastics waste. J. Energy Inst., 92(1): 118-127 (2019).

11. Barrer, R. M. \& Townsend, R. P., Transition metal ion exchange in zeolites. Part 1.Thermodynamics of exchange of hydrated $\mathrm{Mn} 2+, \mathrm{Co} 2+, \mathrm{Ni} 2+, \mathrm{Cu} 2+$ and $\mathrm{Zn} 2+$ ions in ammonium mordenite. J. Chem. Soc. Faraday Trans. 1 Phys. Chem. Condens. Phases, 72: 661-673 (1976).

12. Weidenthaler, C., Mao, Y. \& Schmidt, W., Competitive ion exchange of transition metals in low silica zeolites. in Studies in Surface Science and Catalysis, (eds. Aiello, R., Giordano, G. \& Testa, F.), Elsevier, 142: 1857-1864 (2002).

13. Jha, V. K., Matsuda, M. \& Miyake, M., Sorption properties of the activated carbonzeolite composite prepared from coal fly ash for $\mathrm{Ni2}+, \mathrm{Cu} 2+, \mathrm{Cd} 2+$ and $\mathrm{Pb} 2+$. J. Hazard. Mater., 160(1): 148-153 (2008).

14. Karmacharya, M. S., Gupta, V. K., Tyagi, I., Agarwal, S. \& Jha, V. K., Removal of As(III) and $A s(V)$ using rubber tire derived activated carbon modified with alumina composite. J. Mol. Liq., 216: 836-844 (2016).

15. Wongcharee, S., Aravinthan, V. \& Erdei, L., Mesoporous activated carbon-zeolite composite prepared from waste macadamia nut shell and synthetic faujasite. Chinese J. Chem. Eng., 27(1): 226236 (2019).

16. Foo, K. Y. \& Hameed, B. H., The environmental applications of activated carbon/zeolite composite materials. Adv. Colloid Interface Sci., 162(1-2): 22-28 (2011).

17. Nugrahaningtyas, K. D., Hidayat, Y. \& Saputri, T. D., Pengaruh konsentrasi prekusor logam Co dan Mo terhadap karakter katalis CoMo/USY. ALCHEMY J. Penelit. Kim., 10(1): 40-48 (2014).

18. Sesario, R., Dwi, K., Rahmawati, F., Heraldy, E. \& Rachmadani., Characterization of metal particles on supporting materials mordenite, ultra stable Y zeolita, and natural zeolit. in AIP Conference Proceedings, 1868(1): 020002 AIP Publishing LLC, (2017). 
19. Laksmono, J. A., Sudibandriyo, M., Saputra, A. H. \& Haryono, A., Development of porous structured polyvinyl alcohol/zeolite/carbon composites as adsorbent. in IOP Conference Series: Materials Science and Engineering, 201(1): 012006 IOP Publishing, (2017).

20. Ohlsson, F., Weight reduction by optimized reinforcement structures. in Lightweight Composite Structures in Transport, Woodhead Publishing., 191-215 (2016).

21. Yusmartini, E., Setiabudidaya, D., Ridwan., Marsi. \& Faizal., Preparation of activated carbons from coconuts shell for $\mathrm{Pb}$ (II) adsorption. Adv. Mater. Res., 896: 149-152 (2014).

22. Guo, Y. \& Rockstraw, D. A., Physicochemical properties of carbons prepared from pecan shell by phosphoric acid activation. Bioresour. Technol., 98(8): 1513-1521 (2007).

23. Gusti, A. I. S., Nugrahaningtyas, K. D. \& Heraldy, E., CoMo/USY catalysts prepared by precipitationt methods: effect of $\mathrm{pH}$ treament. in IOP Conference Series: Materials Science and Engineering, 333(1): 012059 IOP Publishing, (2018).

24. Shamsuddin, M. S., Yusoff, N. R. N. \& Sulaiman, M. A., Synthesis and characterization of activated carbon produced from kenaf core fiber using H3PO4 activation. Procedia Chem., 19: 558565 (2016).

25. Mopoung, S., Moonsri, P., Palas, W. \& Khumpai, S., Characterization and properties of activated carbon prepared from tamarind seeds by $\mathrm{KOH}$ activation for
Fe(III) adsorption from aqueous solution. Sci. World J., 2015: 1-9 (2015).

26. Sriatun, S., Taslimah, T., Cahyo, E. N. \& Saputro, F. D., Sintesis dan karakterisasi zeolit Y. J. Kim. Sains dan Apl., 20(1): 19-24 (2017).

27. Wang, B., Wang, D., Guan, Y., Xu, H., Zhang, L. \& Wu, P., Nickel/USY catalyst derived from a layered double hydroxide/zeolite hybrid structure with a high hydrogenation efficiency. ChemCatChem, 9(24): 4552-4561 (2017).

28. Girgis, B. S., Temerk, Y. M., Gadelrab, M. M. \& Abdullah, I. D., X-ray diffraction patterns of activated carbons prepared under various conditions. Carbon Lett., 8(2): 95100 (2007).

29. Omri, A. \& Benzina, M., Characterization of activated carbon prepared from a new raw lignocellulosic material: Ziziphus spinachristi seeds. J. la Société Chim. Tunisie, 14: 175-183 (2012).

30. Seehra, M. S., Geddam, U. K., SchweglerBerry, D. \& Stefaniak, A. B., Detection and quantification of $2 \mathrm{H}$ and $3 \mathrm{R}$ phases in commercial graphene-based materials. Carbon N. Y., 95: 818-823 (2015).

31. Shi, T., Zhu, L., Yin, Z., Shen, X., Lv, Z., Wu, $X .$, Min, $X .$, et al., Preparation and properties of $\mathrm{MgO}-\mathrm{C}$ refractories using sucrose as binder. in IOP Conference Series: Materials Science and Engineering, 678(1): 012092 IOP Publishing, (2019).

32. Lewis, I. C. \& Pirro, T. A., Sugar additives blend useful as a binder or impregnant for carbon products. 1-9 (2003). 